ISSN 2077-1827. Гуманізація навчально-виховного процесу. 2021, №. 1 (100)

РОЗДІЛ ЗАГАЛЬНА ШКОЛА

вони просто не зрозуміли, щзо математика $\epsilon$ сплетінням абстрактної математики і прикладної математики.

Перехід на нові освітні стандарти висуває необхідність вводити прикладну спрямованість икільної освіти. Універсальність математичних методів дозволяє відобразити зв'язок теоретичного матеріалу різних областей знань з практикою. Передбачити всі аспекти застосування математики в майбутній діяльності учнів практично не можливо, а тим більше складно розглянути всі ці питання в школі. Науково-технічна револючія у всіх областях людської діяльності висуває нові вимоги до знань, технічної культури, загального і прикладного характеру освіти. Це ставить перед сучасною школою нові завдання для вдосконалення освіти. Отже, прикладна спрямованість шкільного курсу математики здійснюється з метою підвищення якості природничо-математичної освіти учнів, застосування їх математичних знань до вирішення завдань повсякденного життя $i$ в подальшій професійній діяльності.

У статті обтрунтовується необхідність використання прикладних задач з математики в старших класах закладів середньої освіти, та пропонується комплекс задач.

Задачі прикладного змісту дають можливість для реалізації загальнодидактичних принципів в прочесі навчання математики. Варто також відзначити, щзо саме прикладні завдання можуть використовуватися з різною дидактичною метою: можуть мотивувати, зацікавити, сприяти розвитку розумової діяльності, пояснити зв'язок між математикою та іншими шкільними дисциплінами (фізика, біологія, інформатика, хімія, економіка, тощь), та зв'язок між математикою та нематематичними областями.

Ключові слова: прикладна задача, математична модель, міжпредметні зв'язки, прикладна спрямованість, математика.

УДК 373.5.091.313:51

ORGANIZATION OF PROJECT ACTIVITY IN MATHEMATICS LESSONS AS A WAY OF DEVELOPING COGNITIVE COMPETENCE OF STUDENTS

\title{
ОРГАНІЗАЦІЯ ПРОСКТНОӤ ДІЯЛЬНОСТІ НА УРОКАХ МАТЕМАТИКИ ЯК СПОСІБ РОЗВИТКУ ПІЗНАВАЛЬНОЇ КОМПЕТЕНТНОСТІ УЧНІВ
}

\section{Борис Беседін}

кандидат педагогічних наук, доцент E-mail: besedin_boris@ukr.net ORCID 0000-0003-2157-5252

Researcher ID: E-8627-2018 ДВНЗ «Донбаський державний педагогічний університет», Україна

\section{Анастасія Кириченко}

здобувач 2 (магістерського) рівня вищої освіти спеціальності 01404
Boris Besedin

C.Sc. in Pedagogy, Associate Professor E-mail: besedin_boris@ukr.net ORCID 0000-0003-2157-5252

Researcher ID: E-8627-2018

SHEI "Donbas State Pedagogical University", Ukraine

\section{Anastasiia Kyrychenko applicant 2 (master's) level of higher education specialty 01404}


ISSN 2077-1827. Гуманізація навчально-виховного процесу. 2021, №. 1 (100)

РОЗДІЛ ЗАГАЛЬНА ШКОЛА

Середня освіта (Математика )

E-mail: nastyakirichenko7117@ukr.net

ORCID 0000-0003-4788-3974

Researcher ID: ABB-7619-2021

ДВНЗ «Донбаський державний

педагогічний університет», Україна
Secondary education (Mathematics)

E-mail: nastyakirichenko7117@ukr.net

ORCID 0000-0003-2157-5252

Researcher ID: ABB-7619-2021

SHEI "Donbas State Pedagogical

University", Ukraine

\section{ABSTRACT}

The article highlights the pedagogical problem of using the project method in mathematics lessons. The analysis of psychological and pedagogical literature was carried out and the ways of improving project activity and encouraging students to independently search for solutions to the tasks were considered.

The modern development of education is aimed at forming a competence approach during training. Competence includes: knowledge, skills, experience, values, attitudes. Project activity creates conditions in which the student can gain experience, form values and in accordance with the attitude to mathematics, others and learning. So, when we implement project activities, first of all, we are working on the implementation of a competent approach.

The main task of education is the formation of students "skills and desire to learn all their lives. Therefore, in the modern world, the use of such techniques and methods in the educational process is becoming more and more relevant, which form the ability to independently extract new information, hypothesize, draw conclusions. General didactics and individual techniques within the educational process call for solving problems related to the development of schoolchildren's independence and self-development. And this, in turn, encourages the search for new forms and methods of learning.

Project activity is a very effective method for teaching mathematics. The basis of this method is the involvement of students in active cognitive and creative joint activities in solving one common problem. Everything that a student learns theoretically, he must be able to apply practically to solve problems relating to his life. He needs to know where and how he can apply his knowledge in practice, if not now, then in the future. Project activity of students is a field where there is a need for a connection between knowledge and skills, theory and practice.

Implementation of the project method during the educational process will help students to acquire social skills, develop critical thinking, draw conclusions, based on their own observations and experience, be able to work in a team, take into account different points of view and will help to learn how to apply the acquired knowledge in practice.

Key words: project, project activity, competence, competence approach, research activity, mathematics.

Актуальність теми. Значення математичної освіти в усьому світі зростає 3 кожним роком. Математичні методи проникають у різноманітні сфери діяльності людини, а володіння цими методами визначають іiі успішність. Але, разом 3 тим, на сьогоднішній день спостерігається різке зниження рівня математичної підготовки учнів. Одним 3 найпоширеніших питань на уроках математики є: «Навіщо мені це знадобиться в реальному житті?». Учні часто не 
ISSN 2077-1827. Гуманізація навчально-виховного процесу. 2021, №. 1 (100)

РОЗДІЛ ЗАГАЛЬНА ШКОЛА

бачать зв'язку між тим, що вивчають і тим, що має для них значення і саме цей зв'язок $є$ основою ефективного навчання. Ця проблема спровокувала пошук методу, здатного змінити емоційно-чуттєве ставлення до математики та активізувати діяльність учнів. Одним 3 вирішень цієї проблеми є координація навчального процесу, зосередженого на розвиток творчих здібностей учнів i навичок дослідницької проєктної діяльності.

Застосування в навчальному процесі методу проєктів дозволить сформувати в учнів уявлення про суспільство та допоможе навчитися застосовувати отримані знання на практиці. Тож існує необхідність в узагальненні теоретичного та методичного матеріалу дослідження, а також пошуку шляхів удосконалення методу проєктів на уроках математики.

Аналіз останніх досліджень і публікацій. Питанням застосування методу проєктів в освітньому процесі займались багато вітчизняних та зарубіжних науковців. Засновниками цього методу є американський філософ Д. Дьюї та його учень В. Кілпатрік, вони вважали, що навчання необхідно будувати через практичну діяльність учнів, яка відповідає їх особистій зацікавленості у певній ділянці знань. В.В. Гузеєв та Н.Ю. Пахомова розглядали проєктну діяльність як таку, що представляє собою один з можливих способів проблемного навчання. На думку М.А. Ступницької проєктом є робота, яка спрямована на вирішення певної проблеми за допомогою найбільш оптимального способу. Г.К. Селевко розглядає метод проєктів як системо-утворюючий компонент при описі i характеристиці різних технологій. Е.С. Полат характеризує даний метод як спільну діяльність учителя та учнів, який здійснюється через детальну розробку проблеми, яка повинна завершитися практичним результатом, оформленим тим або іншим способом. Аналізуючи закордонний та вітчизняний досвід можна зробити висновок, що проєктне навчання досить широко використовується в процесі навчання. Але проблема застосування на уроках математики залишається актуальною та потребує подальших пошуків ії розв'язання.

Формулювання цілей (мета) статті, постановка завдання. Основною метою $є$ визначення умов реалізації проєктної діяльності на уроках математики.

Виклад основного матеріалу дослідження 3 повним обгрунтуванням отриманих наукових результатів. В сучасному світі освіченою вважається людина, яка не тільки володіє певними знаннями, а ще вміє самостійно їх здобувати, використовувати на практиці та робити це цілеспрямовано. Тому з'являється потреба вийти за рамки сформованих традиційних підходів та діяти в напрямку, який спонукає до пошуку нової інформації, автономної плідної діяльності, сконцентрованої на формування творчого мислення учнів (Усик, 2012).

В нинішній час в освітню діяльність школи впроваджуються різноманітні інновації. В пріоритеті для застосування стоять активні методи навчання, і метод проєктів серед них також має місце при вивченні математики.

Слово «проєкт» запозичено $з$ латинської й походить від слова «proectus», яке буквально означає «кинутий уперед». У сучасному розумінні проєкт - це намір, який буде здійснено в майбутньому (Наволокова, 2009: 76).

Проєкт - це одна 3 форм дослідницької роботи; сукупність прийомів, операцій, які допомагають оволодіти певною областю практичних чи 
ISSN 2077-1827. Гуманізація навчально-виховного процесу. 2021, №. 1 (100)

РОЗДІЛ ЗАГАЛЬНА ШКОЛА

теоретичних знань в тій чи іншій діяльності; сукупність необхідних матеріалів для створення будь-якого продукту.

В основу технології проєктного навчання на уроках математики покладено ідею про спрямованість навчально-пізнавальної діяльності учнів на результат, який виходить при вирішенні тієї чи іншої практично або теоретично значущої задачі. При такій формі навчання зміст, форми, методи повинні якомога більше враховувати індивідуальні особливості учня, а також бажані способи роботи 3 навчальним матеріалом. Вона націлює на емансипацію учня, усунення його залежності від викладача шляхом самоорганізації і самонавчання в процесі створення конкретного продукту або вирішення однієї або цілого ряду проблем, взятих 3 реального життя.

Зміст проєктної технології розкривається через її принципи:

- зв’язок ідеї проєкту з реальним життям;

- зацікавленість до виконання проєкту зі сторони всіх його учасників;

- самоорганізація та відповідальність;

- провідна роль консультативно-координуючої функції вчителя;

- націленість на створення конкретного продукту;

- монопредметний та міжпредметний характер проєкту;

- структурна та часова завершеність проєкту.

Реалізація методу проєктів під час вивчення математики $\epsilon$ досить перспективною. Робота в цій формі викликає в учнів непідробний інтерес і $\epsilon$ більш результативною, ніж на традиційних уроках.

Проскти можна розділити на п'ять груп (Артишук, 2017) :

1) Дослідницькі. Метою даного проєкту $є$ спростування або підтвердження будь-якої гіпотези. За своєю структурою, навчальна дослідницька діяльність повинна як можна більше імітувати наукову дослідницьку діяльність (Беседін, 2011). Тому виконання такого виду проєкту потребує використання наступного алгоритму:

- виявлення проблеми;

- формулювання гіпотези;

- планування дій;

- збір інформації, іiі аналіз і синтез, зіставлення і обробка даних;

- підготовка та написання звіту;

- захист та презентація проєкту.

Проєкт 3 математики може бути здійснений індивідуально і групою учнів, оформлений традиційно або з підтримкою мультимедійних засобів. Відбуватися дослідження може на уроці або в позаурочний час за сценарієм викладача.

Приклад такого проєкту: «Нестандартні способи вирішення тригонометричних рівнянь»

2) Tворчі. Передбачає довільну форму виконання, варіативність представлення результатів. Результатом виконання такого проєкту може бути: газета, відео, гра, брошура, тощо.

Приклади: створення електронного збірника математичних задач. Під час виконання цього проєкту важливо не лише зосередитись на складанні задач, а розподілити учнів на групи, в яких у кожного є своя роль: автора, редактора, верстальника, дизайнера. Тобто хтось 3 учнів вигадує задачі, хтось робить 
ISSN 2077-1827. Гуманізація навчально-виховного процесу. 2021, №. 1 (100)

РОЗДІЛ ЗАГАЛЬНА ШКОЛА

малюнки до них, хтось оформлює, а хтось верстає. Також прикладом можуть слугувати: створення телеграм або ютуб каналу, в якому будуть публікуватись певні математичні відомості, які відносяться до обраної теми.

Менш сильним учням важче дається математика, але такі заняття, як творчі міні-проєкти їх захоплюють та дають можливість проявити себе , стати центром уваги всього класу, випробувати на собі почуття успіху.

3) Інформаційні. Орієнтований на збір інформації про будь-який математичний об'єкт, явище, особистості вченого, тощо. Метою даного проєкту $\epsilon$ аналіз отриманих відомостей, обробки та подання інформації для аудиторії однокласників. Прикладом може бути створення проєкту-презентації: «Історія многогранників - від найдавніших часів до наших днів».

4) Ігрові. Підготовка та реалізація такого проєкту найбільш енерговитратна та вимагає особливо ретельної підготовки. Беручи участь в ньому, учасники приміряють на собі ролі історичних персон, вигаданих героїв, тощо. Результат даної проєктної діяльності залишається відкритим до самого закінчення. Приклад: створення вистави, в якій розігруються деякі історичні задачі або сцени 3 життя відомих математиків.

5) Практико-орієнтовані. Результат виконання такого проєкту може бути безпосередньо використаний в практиці. Ці проєкти відрізняє чітко визначений із самого початку результат діяльності його учасників. Причому цей результат обов'язково орієнтований на соціальні інтереси самих учасників та може бути використаний в житті класу, школи або міста. Такий проєкт вимагає ретельно продуманої структури, навіть сценарію всієї діяльності його учасників 3 визначенням функцій для кожного 3 них, чітких висновків та участі в оформленні кінцевого продукту. Прикладом можуть слугувати проєкти: «Дослідження вартості будівельних матеріалів для ремонту будинку», «Функції в навколишньому світі», «Геометрія рідного міста».

Головною метою будь-якого проєкту, в тому числі проєкту з математики $є$ формування ключових компетенцій, під якими в сучасній педагогіці розуміють комплексні властивості особистості, що включають знання, вміння, навички, а також готовність застосувати їх в необхідній ситуації.

В процесі проєктної діяльності формуються такі компетенції (Овчарук, 2004: 21):

1. Рефлексивні вміння:

- вміння осмислити завдання, для розв'язання якого не достатньо лише теоретичних знань;

- знати, чому необхідно навчитись для вирішення поставленої задачі.

2. Дослідницькі вміння:

- вміти самостійно знаходити інформацію за допомогою різноманітних джерел;

- вміти використовувати знання з різних областей;

- вміти висувати гіпотези;

- встановлювати причинно-наслідкові зв’язки.

3. Навички роботи в колективі:

- вміння взаємодіяти з будь-яким партнером;

- взаємодопомога в групі для вирішення спільних питань; 
ISSN 2077-1827. Гуманізація навчально-виховного процесу. 2021, №. 1 (100)

РОЗДІЛ ЗАГАЛЬНА ШКОЛА

- вміти знаходити та виправляти помилки в роботі інших учасників.

4. Комунікативні навички:

- вміння вступати в діалог, задавати питання;

- вміння вести дискусію;

- вміння відстоювати свою точку зору.

5. Презентаційні вміння і навички:

- вміння впевнено тримати себе під час презентації;

- вміння користуватися засобами наочності під час виступу;

- вміння відповідати на незаплановані питання.

Проаналізувавши організацію проєктної діяльності, можна виділити наступні етапи (Остапович, 2018) :

1) Підготовчий етап.

На цьому етапі дуже важливо зацікавити учнів та виробити мотивацію до виконання проєкту. На уроках вивчається необхідний теоретичний матеріал. Далі пропонується тема проєкту у вигляді проблеми, пов'язаної з темою уроку. Дуже важливо, щоб ця тема була орієнтована на життєву ситуацію, оскільки це буде посилювати інтерес та спонукати до активної діяльності учнів.

2) Етап планування.

В ході розбору та обговорення проєкту виробляється план спільних дій учня та вчителя. Учні розбиваються на пари або групи (в залежності від кількості осіб в класі) та розподіляють завдання для кожної з них, обирають конкретну тему для своєї проєктної роботи, попередньо визначивши ії необхідність, актуальність та можливість реалізації, складають план дій, розподіляють ролі. До кожного учасника проєкту доводяться критерії оцінки кінцевого результату роботи.

3) Основний етап.

Здійснюється пошук та аналіз інформації на основі друкованої літератури, інтернету, власного досвіду або спостережень. Знайдена інформація обробляється, осмислюється та після обговорення обирається спосіб досягнення кінцевого результату. До зазначеного терміну створюється готовий продукт, як результат проведеного дослідження.

4) Заключний етап.

На заключному етапі учні презентують свої результати. При захисті учні демонструють i коментують важливість розробки поставленої проблеми, іiї актуальність, мету та завдання, пояснюють отриманий результат, дають оцінку своїй діяльності та результативності. Педагог приймає звіт; оцінює вміння виступати, спілкуватися, слухати, обгрунтовувати свою думку; підводить підсумок навчання.

Особливість системи проєктного навчання полягає в тому, що творча робота вчителя і учня є спільною (табл. 1).

Таблиия 1

Діяльність учителя і діяльність учня на етапах роботи над просктом

\begin{tabular}{|c|c|c|}
\hline Етапи роботи & Діяльність учнів & Діяльність учителя \\
\hline 1. Підготовчий & $\begin{array}{l}\text { Обговорюють } \\
\text { дослідження } 3 \text { учителем. Отримуют } \\
\text { додаткову інформацію, уточнюють та } \\
\text { коригують цілі. }\end{array}$ & $\begin{array}{l}\text { Знайомить } 3 \text { задумом } \\
\text { проєкту, мотивує учнів, допомагає в } \\
\text { постановці мети. }\end{array}$ \\
\hline
\end{tabular}


ISSN 2077-1827. Гуманізація навчально-виховного процесу. 2021, №. 1 (100) РОЗДІЛ ЗАГАЛЬНА ШКОЛА

\begin{tabular}{|c|c|c|}
\hline $\begin{array}{r}\text { 2. Планування, } \\
\text { організація діяльності }\end{array}$ & 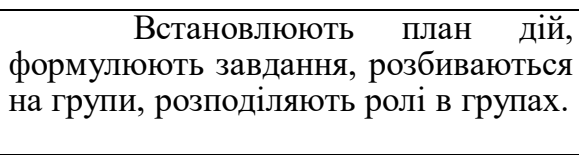 & $\begin{array}{l}\text { Пропонує ідеї, висловлює } \\
\text { припущення щодо вирішення завдань } \\
\text { проєкту. Допомагає в аналізі (за } \\
\text { проханням). }\end{array}$ \\
\hline $\begin{array}{l}\text { 3. Пошуково- } \\
\text { інформаційна } \\
\text { діяльність }\end{array}$ & 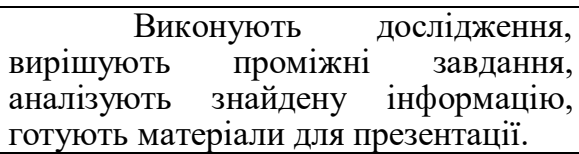 & $\begin{array}{l}\text { Спостерігає, радить, побічно } \\
\text { керує діяльністю, консультує } \\
\text { підготовку до презентації. }\end{array}$ \\
\hline $\begin{array}{lr}\text { 3віт, } \\
\text { проєкту }\end{array} \quad \begin{array}{r}\text { Подання, } \\
\text { презентація }\end{array}$ & $\begin{array}{l}\text { Обговорюють знайдений } \\
\text { спосіб розв'язання проблеми, беруть } \\
\text { участь в в оцінюванні шляхом } \\
\text { колективного обговорення } \\
\text { самооцінок. Захищають проєкт. }\end{array}$ & \begin{tabular}{l} 
Слухає, задає питання в ролі \\
рядового учасника, оцінює \\
\multicolumn{1}{c}{ зусилля учнів, використання } \\
джерел пошукової інформації, \\
результати вирішення проблем, \\
можливості і потенціал продовження \\
дослідження, якість звіту.
\end{tabular} \\
\hline 5. Рефлексія & 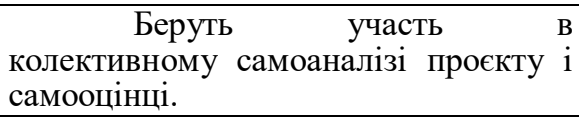 & $\begin{array}{l}\text { Оцінює свою діяльність } 3 \\
\text { педагогічного керівництва діяльністі } \\
\text { дітей. }\end{array}$ \\
\hline
\end{tabular}

Етапи оформлення проєкту (Пєхота, 2001: 152)

I. Учні разом з учителем формують назву проєкту та обирають напрями, за якими будуть працювати. Наприклад назва проєкту: «Майбутня професія i математика».

Окремі напрями:

- математика в біології;

- математика в медицині;

- математика в спорті;

- математика в економіці.

II. Написання проєкту. Він має включати в себе наступні розділи:

- актуальність;

- значущість;

- мета і завдання;

- визначення очікуваних результатів;

- планування готового «продукту» в результаті виконання проєкту.

III. Етап реалізації (визначаються терміни початку та закінчення виконання проєкту).

IV. Механізм реалізації проєкту (даються відповіді на питання: Як? Яким чином? За допомогою яких засобів буде реалізовано проєкт?).

V. Обов'язки та відповідальність (визначається, хто і за що відповідає на кожному з етапів).

VI. Очікувані результати (які результати очікують отримати на кожному 3 етапів та після завершення).

VII. Оцінка й самооцінка проєкту (хто буде брати участь в оцінюванні, форма контролю й оцінки, в якій формі буде подано результат).

Оцінювання проєкту та роль педагога

В ході оцінювання проєкту учитель бере на себе також роль учня, який слухає інформацію, що доходить від інших учнів. Він сам повинен дотримуватися принципу, який говорить про те, що в оцінюванні участі учнів в проєкті на першому місці повинні бути позитивні оцінки, а інформація про слабкі сторони - висловлюється в кінці. 
ISSN 2077-1827. Гуманізація навчально-виховного процесу. 2021, №. 1 (100)

РОЗДІЛ ЗАГАЛЬНА ШКОЛА

Для підведення підсумку, можна спиратись на наступні критерії оцінювання проєкту:

I. Оцінка роботи:

- актуальність та новизна запропонованих розв'язків, складність теми;

- загальний обсяг розробок та кількість запропонованих вирішень;

- практична значимість.

II. Оцінка захисту:

- якість презентації;

- розкриття широти поглядів з теми дослідження;

- відповіді на запитання вчителя/учнів;

- вміння аргументувати свої висновки;

- рівень самостійності учасників проєкту;

- якість оформлення результатів.

Для вчителя додатковим матеріалом в оцінці проєкту є зворотний зв'язок 3 учнями. Найкраще, якщо він отримає його як їх самооцінку, в якій вони дадуть відповідь собі на питання: «Чому я навчився, беручи участь в проєкті?».

Варто підкреслити, що вчитель має право виробити свій стиль контролю за ходом проєкту та оцінювання. Однак він не повинен в цьому стилі обмежувати суб'єктивність учнів, наприклад, надаючи їм готові концепції, що стосуються того, як вирішувати окремі проблеми. Це не відповідає принципам консультації, а крім того, обмежує почуття відповідальності учнів. Від того, наскільки вони відчують свою відповідальність по відношенню до себе за результати і цінності, досягнуті в проєкті, залежить, в значній мірі їх мотивація до безперервної освіти.

Розглянемо реалізацію методу проєктного навчання на прикладі теми: «Показникова функція» курсу алгебри 11 клас.

Проєкт «Показникова функція та ऑї застосування в різних сферах діяльності житті людини»

Алгебра 11 клас.

(Практико-орієнтований проєкт)

Практична значущість проєкту заключається в тому, що він дозволяє об'єктивно оцінити значимість показникової функції, спираючись на розглянуті факти, розкриваючи особливості застосування в житті людини.

Мета: знайти практичне застосування теоретичних знань про показникову функцію в різних сферах діяльності людини.

Завдання проєкту:

- довести, що функціональні залежності існують в усіх сферах життя;

- розширити знання про показникову функцію;

- дізнатися, які явища 3 життя та науки описує показникова функція;

- навчитися застосовувати отримані знання в нестандартних ситуаціях на основі розглянутих прикладів із реального життя при розв'язанні практикоорієнтованих задач.

Дана робота складається з таких етапів:

1. Теоретичне опрацювання відомостей про показникову функцію (означення, властивості, графік, показникові рівняння та нерівності); 
ISSN 2077-1827. Гуманізація навчально-виховного процесу. 2021, №. 1 (100)

РОЗДІЛ ЗАГАЛЬНА ШКОЛА

2. Підбір, вивчення, аналіз інформації про функції, зокрема показникової функції;

3. Дослідження властивостей показникової функції;

4. Приклади застосування показникової функції в житті людини.

Термін реалізації: 2 тижні, після вивчення основного матеріалу 3 даної теми.

I. Підготовчий етап.

Хід проєкту

Вивчити основний теоретичний матеріал стосовно відомостей про показникову функцію. Обрати тему про застосування показникової функції із запропонованих:

1) показникова функція в природі та техніці;

2) показникова функція в науці (фізика, біологія, хімія);

3) показникова функція в економіці;

4) показникова функція в повсякденному житті.

II. Етап планування.

Формуються групи за обраними темами. Учитель обговорює 3 кожною групою тему дослідження, джерела пошуку інформації та форму представлення результатів. Уточнюються терміни реалізації кожного етапу роботи: збору, обробки інформації, створення кінцевого продукту.

III. Основний етап

Пошук задач практичного змісту за обраною темою, які можна вирішити за допомогою знань про показникову функцію. Вирішення цих задач, або розбір розв'язку, якщо вони присутні в джерелі інформації. Оформлення знайденого матеріалу у вигляді мультимедійної презентації.

IV. Заключний етап.

На узагальнюючому уроці з теми «Показникова функція» учні виступають 3 презентаціями за обраними темами.

Роботи оцінюються всіма учнями, враховуючи:

- відповідність матеріалу темі дослідження;

- вміння застосовувати теоретичні знання з теми;

- наочність та виразність;

- вміння швидко відповідати на запитання вчителя та опонентів;

- якість оформлення презентації.

Висновки та перспективи подальших розвідок у даному напрямку. Отже, сьогодні можна багато казати про причини популярності методу проєктів на уроках математики, але найголовніша 3 них - це розвиток компетенцій учнів, які так необхідні в сучасному світі.

Проєктна діяльність 3 математики - це така навчально-пізнавальна діяльність учнів, яка спрямована на отримання деякого заздалегідь спланованого особистісно значимого для них практичного результату і передбачає самостійне вирішення учнями математичних задач. Технологія організації та проведення проєктного навчання передбачає комбінування способів, методів, прийомів, форм і засобів навчання.

Результатом роботи є декілька методичних рекомендацій для організації роботи над проєктом на уроках математики: 
ISSN 2077-1827. Гуманізація навчально-виховного процесу. 2021, №. 1 (100)

РОЗДІЛ ЗАГАЛЬНА ШКОЛА

1) Тема проєктів повинна бути відома заздалегідь. Учні повинні бути орієнтовані на співставлення та порівняння деяких фактів з історіїі математики, різних підходів до розв'язання тих, чи інших проблем.

2) Необхідно грамотно сформулювати цілі, бо саме цілі $є$ рушійною силою кожного проєкту, i всі зусилля учасників спрямовані на те, щоб їх досягти.

3) Проблема, яка пропонується учням, формулюється таким чином, щоб зорієнтувати їх на пошук знань з різноманітних джерел інформації.

4) Необхідно залучити до роботи над проєктом якомога більше учнів класу, запропонувавши кожному завдання 3 урахуванням рівня його математичної підготовки.

Таким чином, використання проєктної діяльності під час навчання математики в сучасній школі стає все більш актуальним та потребує подальших пошуків шляхів ㄲï реалізації. Метод проєктів дає можливість об'єднувати різноманітні типи роботи, роблячи процес навчання найбільш цікавим, найбільш захоплюючим і з цієї причини найбільш результативним.

\section{ДЖЕРЕЛА I ЛІТЕРАТУРА}

Артишук Г.М. (2017). Організація проектних технологій у навчальновиховному процесі. Оконськ, 46 с.

Беседін Б.Б., Крилова І.В. (2011). Формування елементів дослідницької діяльності у учнів старших класів. Збірник наукових праць фізикоматематичного факультету СДПУ. Вип. №1 С. 132-137.

Наволокова Н.П. (2009). Енциклопедія педагогічних технологій та інновацій. Харків: Вид. група «Основа», 176 с.

Овчарук О.В. (2004). Компетентнісний підхід у сучасній освіті: світовий досвід та українські перспективи: Бібліотека 3 освітньої політики. Київ: ВЦ «K.I.C.», 112 c.

Остапович 3.П. (2018). Проектна технологія навчання на уроках математики. Острог, 94 с.

Пєхота О.М., Кіктенко А.З., Любарська О.М. (2001). Освітні технології. Київ: ВЦ «А.С.К.», 256 с.

Усик О.В. (2012). Запровадження нових технологій у традиційну систему навчання методом проектів. Математика в сучасній школі. Вип. №1(124) С. 33-39.

\section{REFERENCES}

Artyshuk H.M., (2017). Orhanizatsiia proektnykh tekhnolohii u navchalnovykhovnomu protsesi [Organization of project technologies in the educational process]. Okonsk [in Ukrainian].

Besedin, B.B. \& Krylova, I.V. (2011) Formuvannia elementiv doslidnytskoi diialnosti u uchniv starshykh klasiv [Formation of elements of research activity in high school students.]. Zbirnyk naukovykh prats fizyko-matematychnoho fakultetu SDPU Collection of scientific works of the Faculty of Physics and Mathematics of SDPU,1, 132-137 [in Ukrainian].

Navolokova, N.P. (2009). Entsyklopediia pedahohichnykh tekhnolohii ta innovatsii [Encyclopedia of pedagogical technologies and innovations]. Kharkiv: Osnova [in Ukrainian]. 
ISSN 2077-1827. Гуманізація навчально-виховного процесу. 2021, №. 1 (100)

РОЗДІЛ ЗАГАЛЬНА ШКОЛА

Ovcharuk, O.V. (2004). Kompetentnisnyi pidkhid u suchasnii osviti: svitovyi dosvid ta ukrainski perspektyvy: Biblioteka z osvitnoi polityky [Competence approach in modern education: world experience and Ukrainian perspectives: Library for Educational Policy]. Kyiv: K.I.S. [in Ukrainian].

Ostapovych, Z.P. (2018). Proektna tekhnolohiia navchannia na urokakh matematyky [Project learning technology in math lessons]. Ostroh [in Ukrainian].

Piekhota, O.M., Kiktenko, A.Z. \& Liubarska, O.M. (2001). Osvitni tekhnolohii [Educational technologies]. Kyiv: A.S.K. [in Ukrainian].

Usyk, O.V. (2012). Zaprovadzhennia novykh tekhnolohii u tradytsiinu systemu navchannia metodom proektiv [Introduction of new technologies in the traditional system of project learning]. Matematyka $v$ suchasnii shkoli-Mathematics in Modern School, 1, 33-39 [in Ukrainian].

\section{АНОТАЦІЯ}

В статті висвітлено педагогічну проблему застосування методу проєктів на уроках математики. Проведено аналіз психолого-педагогічної літератури та розглянуто шляхи вдосконалення проєктної діяльності та заохочення учнів до самостійного пошуку вирішення поставлених задач.

Сучасний розвиток освіти спрямований на формування компетентнісного підходу під час навчання. Компетентність включає в себе: знання, уміння, досвід, цінності, ставлення. Проєктна діяльність створює умови, в яких учень може набути досвіду, сформувати иінності і відповідно ставлення до математики, оточуючих та навчання. Тож, коли ми впроваджуємо проєктну діяльність, то перш за все, ми працюємо над впровадженням компетентнісного підходу.

Основним завданням освіти є формування в учнів вміння $і$ бажання вчитися все життя. Тому в сучасному світі все більш актуальним стає використання в освітньому проиесі таких прийомів $і$ методів, які формують вміння самостійно добувати нову інформацію, висувати гіпотези, робити висновки. Загальна дидактика та окремі методики в рамках навчального процесу закликають вирішувати проблеми, пов'язані з розвитком у школярів самостійності та саморозвитку. А цее, в свою чергу, спонукає до пошуку нових форм і методів навчання.

Проєктна діяльність виявляється досить ефективним методом при навчанні математики. В основі изього методу лежить залучення учнів до активної пізнавальної та творчої спільної діяльності при вирішенні однієї загальної проблеми. Все, щуо учень пізнає теоретично, він повинен вміти застосовувати практично для вирішення проблем, щзо стосуються його життя. Він повинен знати, де $і$ як він зможе застосувати свої знання на практиці, якщо не зараз, то в майбутньому. Проєктна діяльність учнів - сфера, де є потреба у зв'язку між знаннями і вміннями, теорією і практикою.

Реалізачія методу проєктів під час навчального процесу допоможе учням в набутті соціальних навичок, розвитку критичного мислення, вмінні робити висновки, спираючись на власні спостереження та досвід, вміти праџювати в команді, враховувати різні точки зору та допоможе навчитись застосовувати отримані знання на практиці.

Ключові слова: проєкт, проєктна діяльність, компетентність, компетентнісний підхід, досліднищька діяльність, математика. 